\title{
A STUDY ON THE ICTHYOFAUNA OF AYMANAM PANCHAYATH, IN VEMBANAD WETLAND, KERALA
}

\author{
S. Prasanth Narayanan ${ }^{1}$, T. Thapanjith and A.P. Thomas
}

School of Environmental Sciences, Mahatma Gandhi University, Thevara Buildings, Gandhi Nagar, Kottayam, Kerala 686008, India Email: ${ }^{1}$ narayanankc@gmail.com

\begin{abstract}
A study on the icthyofauna of Aymanam Panchayath was carried out. A total of 37 species of fishes belonging to 18 families and nine orders were recorded. Order Perciformes showed maximum family diversity. The highest number of species belonged to family Cyprinidae. Nine of the 34 freshwater species recorded are threatened. One exotic species Poecilia reticulata was also noted.
\end{abstract}

KEYWORDS

Aymanam Panchayath, catalogue, ichthyofauna, India, Kerala, threatened, Vembanad

There are 41 west flowing and three east flowing rivers originating from the Western Ghats of Kerala having a total length of $32,000 \mathrm{~km}$. Kerala abounds with many wetlands including lakes, canals, ponds, paddy fields etc. Two-hundredand-ten species of freshwater fishes have been identified from Kerala, of which more than 26 species are considered endemic (Shaji \& Nair, 2003). Most of the fishes are characterized by vibrant attractive colours and shades. Some fishes are of ornamental varieties having high potential in domestic and international markets (Radhakrishnan \& Kurup, 2002).

The study area is the Aymanam Panchayath. The study was conducted in the monsoon and post monsoon periods of 2003 and 2004. Aymanam Panchayath is located between the two main branches of Meenachil river namely Pennar in the north and Kavanar in the south. There are several canals crisscrossing the Panchayath with Arpookkara Panchayath in the east and Vembanad estuary on the west. Vembanad-Kol wetland was designated as a Ramsar site in November 2002. Organically rich sedimentary substratum of the inshore regions of the estuary is a highly preferred habitat for fish and shrimp breeding (Sreekumar, 2003). The western part of the panchayath lies below the mean sea level.

\section{Methodology}

The Ayamanam Panchayath was surveyed for fishes during two seasons. Twelve sampling sites were fixed in different locations all through the panchayath. Samples were collected by using hook and line method, cast net, gill net and from local fishermen. The specimens that could be identified on site were examined and released. Unidentified fishes caught during the survey were labelled along with the vernacular names, preserved and brought to the laboratory for further study. Identification was done with the help of standard references.

\section{Results AND Discussion}

A total of 34 species of freshwater fishes and three species of estuarine fishes belonging to 18 families and nine orders were identified (Table 1). In the present study family Cyprinidae was represented by 10 species, showed maximum diversity (29.41\%). An exotic species Poecilia reticulata was collected from small ditches, which may have been introduced for controlling mosquito larvae (Daniels, 2002). Of the 37 species Ompok malabaricus (Goan Catfish) and Hyporhampus xanthopterus (Vembanad Halfbeak) are Critically Endangered (CR), Labeo dussumieri, Horabagrus brachysoma, Tetradon travancoricus are endangered (EN) and Puntius vittatus, Anabas testudineus, Mystus vittatus, Pristolepis marginatus and Heteropneutes fossilis come under vulnerable (VU) category. Parluciosoma daniconius, Puntius sophore, Nandus nandus and Xenentodon cancila etc. come under lower risk-near threatened (LR-nt) category (Molur \& Walker, 1998; Anon., 1999). 50\% of the fishes reported from the area are currently considered as nonthreatened species (Fig. 1). Five Western Ghats endemic species including two Kerala endemic species were identified in which Pristolepis marginatus was considered as endemic to Kerala, but it has been collected from Tamil Nadu and Karnataka also (Rema Devi et al., 2000). The occurrence of these species in Kerala has been reported by Ramesh et al. (2003). Of the 37 species of fishes identified, $89.18 \%$ (33 species) have ornamental value (Daniels, 2002; Mercy et al., 2002; Radhakrishnan \& Kurup, 2002; Sekharan et al., 2002).

All, except Aplocheilus blockii, A. lineatus, Poecilia reticulata, Chelenodon sp. and Tetraodon travancoricus are used as food. Among the fishes used as food, Etroplus suratensis is highly priced. As per the report of the locals Tetraodon travancoricus and Chelenodon sp. are not even used as poultry feed, as they are poisonous due to the presence of bacteria living inside (Mathai, pers. comm. 2003) and poisonous secretions in the bare spines (M. Krishnan, pers. comm.). However, detailed study is needed to confirm their poisonous nature.

\section{Conclusion}

The salt-water barrage built at Thannermukkom appeares to have played a significant role in the fluctuation of physicochemical parameters of the southern portion of the lake (Padmakumar et al., 2002). The unscientific fishing (poisoning) and the increased pollution of the Vembanad lake due to tourist boats and hotels also have a role in the decline of the fish diversity of the area, as the wetland waters here are closely connected with Vembanad lake. The fish disease, Epizootic Ulcerative Syndrome has constantly affected the fishes of this region. Once the presence of mangrove plants and swamps favoured the egg laying activity of fishes, but because of the 
Table 1. List of fishes of Aymanam Panchayath with vernacular names, categories and economic importance

\begin{tabular}{|c|c|c|c|c|c|}
\hline Scientific Name & Common Name & Vernacular Name & Endemism & IUCNStatus & Economic Importance \\
\hline \multicolumn{6}{|l|}{$\begin{array}{l}\text { Order: Cypriniformes } \\
\text { Family: Aplocheilidae }\end{array}$} \\
\hline Aplocheilus lineatus (Valenciennes) & Tiger Panchax & Poonjan & Southern India & & Poultry feed, Aquarium species \\
\hline Aplocheilus blockii (Arnold) & Little Panchax & Poonjan & Western Ghats & & Poultry feed, Aquarium species \\
\hline $\begin{array}{l}\text { Family: Cyprinidae } \\
\text { Danio malabaricus (Jerdon) }\end{array}$ & Giant Danio & Vayampu, Paral & & & Edible, Aquarium species \\
\hline $\begin{array}{l}\text { Rasbora daniconius } \\
\text { (Hamilton-Buchanan) }\end{array}$ & Blackline Rasbora & $\begin{array}{l}\text { Thuppalukothi, } \\
\text { Thuppalumathi }\end{array}$ & & LRnt & Edible, Aquarium species \\
\hline Puntius amphibius (Valenciennes) & Scarletbanded Barb & Urulanparal & & & Edible, Aquarium species \\
\hline Puntius filamentosus (Valenciennes) & Blackspot Barb & $\begin{array}{l}\text { Kotichipparal, } \\
\text { Poovalipparal }\end{array}$ & & & Edible, Aquarium species \\
\hline $\begin{array}{l}\text { Puntius sarana subnasutus } \\
\text { (Valenciennes) }\end{array}$ & Peninsular Olive Barb & Kuruva & Southern India & & Edible, Aquarium species \\
\hline Puntius sophore (Hamilton) & Softfin Barb & Paral & & LRnt & Edible, Aquarium species \\
\hline Puntius vittatus (Day) & Kooli Barb & Vattakkali,Kaippa & & VU & $\begin{array}{l}\text { Poultry feed, Aquarium species } \\
\text { and edible }\end{array}$ \\
\hline Labeo dussumieri (Valenciennes) & Kerala Labeo & Pullan & & EN & Edible, Cultivable \\
\hline Garra mullya (Sykes) & Brown Algae Eater & Kallemutti, Kallelokkan & India & & Edible, Aquarium species \\
\hline $\begin{array}{l}\text { Amblypharyngodon melettinus } \\
\text { (Valenciennes) }\end{array}$ & Attentive Carplet & Vayampu & & & $\begin{array}{l}\text { Edible, Aquarium species, } \\
\text { Poultry feed }\end{array}$ \\
\hline $\begin{array}{l}\text { Family: Poecilidae } \\
\text { Poecilia reticulata (Peters) }\end{array}$ & Guppy & & & & Aquarium species \\
\hline $\begin{array}{l}\text { Order: Siluriformes } \\
\text { Family: Bagridae } \\
\text { Horabagrus brachysoma (Day) }\end{array}$ & Yellow Catfish & Manjakkori & Western Ghats & EN & $\begin{array}{l}\text { Edible, Cultivable and Aquarium } \\
\text { species }\end{array}$ \\
\hline Mystus gulio (Hamilton-Buchanan) & Longwhiskered Catfish & Vellakkori & & & Aquarium species, Edible \\
\hline Mystus vittatus (Bloch) & Striped Dwarf Catfish & Chillan & & VU & Aquarium species, Edible \\
\hline $\begin{array}{l}\text { Family: Heteropneustidae } \\
\text { Heteropneustes fossilis (Bloch) }\end{array}$ & Stinging Catfish & Kaari & & VU & Aquarium species, Edible \\
\hline $\begin{array}{l}\text { Family: Siluridae } \\
\text { Ompok malabaricus (Valenciennes) }\end{array}$ & Goan Catfish & Thlappan & Western Ghats & CR & Eatable \\
\hline Wallago attu (Schneider) & Boal & Valah & & LRnt & Aquarium species, Edible \\
\hline $\begin{array}{l}\text { Order: Mugiliformes } \\
\text { Family: Mugilidae } \\
\text { Mugil cephalus (Linneaus) }\end{array}$ & Mullet & Kanampu & & & Edible and Cultivable \\
\hline $\begin{array}{l}\text { Order: Beloniforemes } \\
\text { Family: Belonidae } \\
\text { Xenentodon cancila } \\
\text { (Hamilton-Buchanan) }\end{array}$ & Freshwater Garfish & Kola, Kolan & & LRnt & Edible, Aquarium species \\
\hline $\begin{array}{l}\text { Family: Hemirhmphidae } \\
\text { Hyporhampus xanthopterus } \\
\text { (Valenciennes) }\end{array}$ & Vembanad Halfbeak & Morasu & Kerala & $\mathrm{CR}$ & Edible, Aquarium species \\
\hline $\begin{array}{l}\text { Order: Synbranchiformes } \\
\text { Family: Mastacemelidae } \\
\text { Mastacembelus armatus (Lacepede) }\end{array}$ & Tyre-trackspiny Eel & Aarakan & & & Aquarium species, Edible \\
\hline $\begin{array}{l}\text { Order: Perciformes } \\
\text { Family: Anabantidae } \\
\text { Anabas testudineus (Bloch) }\end{array}$ & Climbing Perch & Kallada & & VU & Edible, Aquarium species \\
\hline $\begin{array}{l}\text { Family: Belonntidae } \\
\text { Macropodus cupanus (Valenciennes) }\end{array}$ & Indian Paradise fish & Karimkana & & & Aquarium species, Poultry feed \\
\hline Macropodus cupanus dayi (Day) & Day's Paradises fish & Karimkanna & Kerala & & Aquarium species, Poultry feed \\
\hline $\begin{array}{l}\text { Family: Channidae } \\
\text { Channa striatus (Bloch) }\end{array}$ & Banded Snakehead & Varal & & LRIC & Edible, Aquarium species \\
\hline Channa marulius (Hamilton-Buchanan) & Giant Snakehead & Cherumeen & & LRnt & Edible, Aquarium species \\
\hline $\begin{array}{l}\text { Family: Cichlidae } \\
\text { Etroplus suratensis (Bloch) }\end{array}$ & Banded Pearl Spot & Karimeen,Kariyamplach & & & Edible, Aquarium species \\
\hline
\end{tabular}




\begin{tabular}{|c|c|c|c|c|c|}
\hline Scientific Name & Common Name & Vernacular Name & Endemism & IUCNStatus & Economic Importance \\
\hline Etroplus maculatus (Bloch) & Orange Chromide & Pallathiv & & & Edible, Aquarium species \\
\hline $\begin{array}{l}\text { Family: Gobiidae } \\
\text { Glossogobius giuris } \\
\text { (Hamilton-Buchanan) }\end{array}$ & Tank Goby & Poolan & & & Aquarium species, Edible \\
\hline Awaous sp. & & Pukalappoolan & & & Aquarium species, Edible \\
\hline $\begin{array}{l}\text { Family: Nandidae } \\
\text { Nandus nandus (Hamilton-Buchanan) }\end{array}$ & Mottled Leaf fish & Muthuvala & & LRnt & Edible, Aquarium species \\
\hline Pristolepis marginatus (Jerdon) & Malabar Catopra & Pannakarimeen & Western Ghats & VU & Aquarium species, Edible \\
\hline
\end{tabular}

WG - Endemc to Western Ghats; SI - Endemic to South India; LRnt - Lower risk near threatened; K - Endemic to Kerala; EN - Endangered; LRIc - Lower risk least concern; I - Enndemic to India; VU - Vulnerable; EXO - Exotic

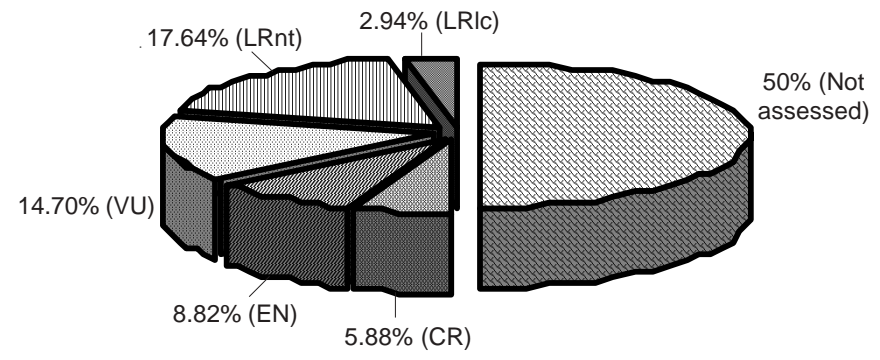

Figure 1. Status of fishes in the study area

destruction of mangrove vegetation, habitat destruction and pollution load, now the fish fauna of this wetland is under threat.

\section{REFERENCES}

Beavan, R. (1982). Handbook of the Freshwater Fishes of India. Narendra Publishing House. New Delhi, 247pp.

Daniels, R.J.R. (2002). Freshwater Fishes of Peninsular India. Universities Press Pvt. Ltd, 288pp.

Day, F. (1889). The Fauna of British India Including Ceylon and Burma Fishes. Vol. I and II. Today and Tomorrow's Printers. New Delhi. Second Reprint, 548pp \& 509pp

Devi, K.R., T.J. Indra, M.S. Ravichandran and M.B. Raghunathan (2000). On a report of Pristolepis marginatus Jerdon (Perciformes: Percoidei: Nandidae) from Karnataka. Journal of the Bombay Natural History Society 97(3): 440

Anon. (1999). Fresh Water Fishes of India, Report Summary 1998. Zoos' Print 14(3): 1-27.

Jayaram, K.C. (1999). The Freshwater Fishes of the Indian Region. Narendra Publishing House, Delhi, 551pp.

Menon, A.G.K. (1997). Rare and Endangered Fishes of Malabar, India. Zoos' Print 12(11): 6-19.

Mercy, T.V.A., R. Thomas and E. Jacob (2002). Potential ornamental fishes of the Western Ghats, pp.151-161. In: Riverine and Reservoir Fisheries of India. Society of Fisheries Technologists (India), Cochin, $678 \mathrm{pp}$.

Molur, S. and S. Walker (Eds.) (1998). Report of the workshop "Conservation Assessment and Management Plan for Freshwater Fishes of India". Zoo Outreach organisation, CBSG India, Coimbatore, India, $156 \mathrm{pp}$

Nair, A.G. and C.P. Shaji (2003). Freshwater fish diversity problems and prospects. Kerala Calling 23(9): 9-11.

Padmakumar, K.G. (2003). Conservation and Management of Vembanad Wetlands, Kerala, pp.65-73. In: Vembanad Water Bird Count (Sreekumar Ed.). Dept. of Forest and Wildlife, Govt. of Kerala, 86pp. Padmakumar, K.G., A. Krishnan, R. Radhika, P.S. Manu and C.K. Shiny (2002). Open water fishery interventions in Kuttanad, Kerala, with reference to fishery decline and ecosystem changes,pp.15-24. In: Riverine and Reservoir Fisheries of India. Society of Fisheries Technologists (India), Cochin, 678pp.

Radhakishnan, K.V and B.M. Kurup (2002). Habitat Preference and Biodiversity of Potential Freshwater Ornamental Fishes of Kerala, pp.162-171. In: Riverine and Reservoir Fisheries of India. Society of Fisheries Technologists (India), Cochin, 678pp.

Ramesh, B.R., P.V. Karunakaran, M. Balasubramanian, L.D. Seen and O.P. Kaler (2003). A Brief Outline of Biodiversity Conservation and Action Plan for Kerala. Kerala Forest and Wildlife Dept., Kottayam, 158-165pp.

Sekharan, M., P.K. Pramod and A. Ramachandran (2002). Role of Chalakkudy Riverine Resources in the Ornamental Fish Marketing Sector of Kerala, pp.384-392. In: Riverine and Reservoir Fisheries of India. Society of Fisheries Technologists (India), Cochin, 678pp.

Sreekumar, B. (Ed.) (2003). Vembanad Water Bird Count. Dept. of Forest and Wildlife, Govt. of Kerala. Kottayam, 44pp.

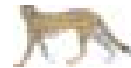

\section{Advt. No. WII/RES/A.3.6(3)-2005 \\ Engagement of Research Personnel for various Research Projects/Cells}

The Wildlife Institute of India (WII), a premier national autonomous Institute of the Ministry of Environment and Forests (MoE\&F), Government of India, wishes to engage 18 research personnel (4Research Associates, 9-J unior Research Fellows \& 5-Technical Assistants) for its various research projects/cells. The last date for receiving the duly filled-in applications is 26th August, 2005 and the interview is likely to be held during the third week of September, 2005 at WII. Details of the available positions along with their essential and desirable qualifications, terms \& conditions, and how to apply are hosted on the Institute's website http:// www.wii.gov.in/

\section{DIRECTOR}

Wildlife Institute of India, Dehra Dun 